Ambiente \& Água - An Interdisciplinary Journal of Applied Science
ISSN 1980-993X - doi:10.4136/1980-993X
www.ambi-agua.net
E-mail: ambi.agua@gmail.com

\title{
Collaborative governance and watershed management in biosphere reserves in Brazil and Canada
}

\author{
ARTICLES doi:10.4136/ambi-agua.2225
}

Received: 21 Dec. 2017; Accepted: 06 Mar. 2018

\author{
Maria Inês Paes Ferreira ${ }^{1 *}$; Pamela Shaw ${ }^{2}$; Graham Kenneth Sakaki; \\ Taylor Alexander ${ }^{2}$; Jade Golzio Barqueta Donnini³ ${ }^{3}$ Virgínia Vilas Boas Sá Rego ${ }^{4}$ \\ ${ }^{1}$ Instituto Federal de Educação, Ciência e Tecnologia Fluminense (IFF), Macaé, RJ, Brasil \\ Programa de Pós-graduação em Engenharia Ambiental (PPEA) \\ E-mail: ines_paes@yahoo.com.br \\ ${ }^{2}$ Vancouver Island University (VIU), Nanaimo, British Columbia, Canada \\ Mount Arrowsmith Biosphere Region Research Institute (MABRRI) \\ E-mail: pam.shaw@viu.ca, graham.sakaki@gmail.com, mrtayloralexander@gmail.com \\ ${ }^{3}$ Instituto Federal de Educação, Ciência e Tecnologia Fluminense (IFF), Macaé, RJ, Brasil \\ Núcleo de Pesquisa em Petróleo, Energia e Recursos Naturais (NUPERN) \\ E-mail: jadegolzio@gmail.com \\ ${ }^{4}$ Universidade Cândido Mendes (UCAM), Nova Friburgo, RJ, Brasil \\ Instituto Universitário Cândido Mendes. E-mail: virginiasarego@uol.com.br \\ *Corresponding author
}

\begin{abstract}
Water management within vulnerable ecosystems managed by multiple jurisdictions can be very complex. This study compares regulatory environments and deconstructs the approaches used for watershed governance and environmental management inside two UNESCO's Biosphere Reserves to identify possible transferability between the two management entities. Three methodological approaches were applied: participatory observation, in-depth interviews of key informants, and document research. We concluded that while there are differences between the regulatory frameworks and localized practices, at a foundational level the goals and desired outcomes relating to environmental protection are not dependent on location, but mainly on the integration and the establishment of common objectives among the diverse social actors involved in the management and from the interaction between different organisms of social control. Additionally, there are elements in the application of regulations and practices in both locales that could be transferred to other jurisdictions interested in addressing watershed protection in vulnerable ecosystems governed by multiple jurisdictions.
\end{abstract}

Keywords: biosphere reserves, ecosystem based management, watershed committees.

\section{Governança colaborativa e gestão de bacias hidrográfica em reservas de biosfera no Brasil e Canadá}

\section{RESUMO}

A gestão da água dos ecossistemas vulneráveis contida em múltiplas jurisdições pode ser muito complexa. Este estudo compara os ambientes regulatórios e desconstrói as abordagens utilizadas para a governança das bacias hidrográficas e o gerenciamento ambiental dentro de 
duas Reservas da Biosfera da UNESCO para identificar possíveis transferências entre as duas entidades de gerenciamento. A metodologia empregada na investigação empregou entrevistas com informantes-chave, observação participante e análise documental. Concluímos que, embora existam diferenças entre os quadros regulatórios e as práticas localizadas, em um nível fundamental, as metas e os resultados desejados relacionados à proteção ambiental não dependem da localização, mas fundamentalmente da integração e do estabelecimento de objetivos comuns aos diversos atores sociais envolvidos na gestão e da interação entre diferentes organismos de controle social. Além disso, existem elementos na aplicação de regulamentos e práticas em ambos os locais que poderiam ser transferidos para outras jurisdições interessadas em abordar a proteção de bacias hidrográficas em ecossistemas vulneráveis governados por várias jurisdições.

Palavras-chave: comitês de bacias hidrográficas, gestão ecossistêmica, reservas da biosfera.

\section{INTRODUCTION}

Well established regulations relating to environmental protection are in place in many nations worldwide. However, the application of these regulations and the involvement of multiple jurisdictional authorities can result in conflicts or, more importantly, gaps in regulatory protections. Two case studies that examine the jurisdictional authority and the application of regulations are considered here: first, the environmental policies, regulations, and laws that have been adopted in Brazil since the 1980s are investigated through a lens that examines the legal tools themselves, looks at jurisdictional overlaps, and then evaluates the practical application of these protectionist mechanisms. The second example considers the legislative landscape that shapes watershed protection in Canada, more specifically the province of British Columbia. The regulatory landscape in both nations is considered within the context of two biosphere reserves, which are regions designated by the United Nations Educational, Scientific, and Cultural Organization (UNESCO) as model sites for improving the relationship between people and nature. In Brazil, Hydrographic Region VIII of the state of Rio de Janeiro (RH-VIII) is considered, while the Mount Arrowsmith Biosphere Region is the focus for the Canadian case study. The selected areas were chosen as they represent the concept of "contested spaces" where conflicts exist among users, either in day-to-day activities or in goals and objectives relating to a desired future, and decision-making is complicated due to layered jurisdictional authorities. The case study in Brazil represents more than two decades of participation and resolution, while the Canadian study discusses an unsuccessful attempt at joint management followed by a new approach to shared-decision making and goal achievement. As will be revealed, the Brazilian example offers direction and "lessons learned" to the evolving Canadian example.

\section{MATERIALS AND METHODS}

The characterization of the two management entities studied here is based on three methodological approaches: participatory observation, in-depth interviews of key informants, and document research. In addition to document and archival investigation on the legal and official environmental framework in Canada and Brazil, bibliographic research on studies relating to democratic governance and participatory environmental management, with a focus on academic work relating to environmentally threatened areas and watersheds, was also completed. In addition, in-depth interviews added to knowledge on the two study areas, and were critical in understanding the evolution of watershed management techniques. 


\subsection{Characterization of the studied regions: RH-VIII (state of Rio de Janeiro) and MABR (British Columbia)}

The Brazilian case study focuses on the Macaé River Watershed Committee (Macaé River WSC), a participatory environmental governance forum created in the state of Rio de Janeiro in 2003. This Committee is responsible for managing Rio de Janeiro's VIII ${ }^{\text {th }}$ Hydrographic Region (RH-VIII), which covers the Macaé River Basin (Figure 1), the Ostras River Basin, the Imboassica Lagoon Basin, and other small coastal creeks and wetlands. It is a very complex territory that involves six municipalities with diverse political and administrative perspectives (Macaé, Nova Friburgo, Casimiro de Abreu, Rio das Ostras, Conceição de Macabu, and Carapebus). There are different ecosystems from the mountain areas in which the headwaters are located (composed by rough rocky terrain and steep river valleys) to coastal areas of estuarine alluvial plains (with low and sprawling sandy riverbeds, subjected to frequent floods in the rainy season). Cultural, social and economic aspects also vary from upper to lower RHVIII areas. Family tourism, agriculture, and livestock are the main activities in the upper area. Urban and industrial patterns are predominant in the lower area, which has experienced intense economic growth over the last twenty-five years, impacted by offshore petroleum exploitation in Campos Basin (SEA and INEA, 2014). The lower part of RH-VIII is consequently more populated, wealthy, and holds political power. Macaé River Basin is strategic to Brazil as it supplies all the necessary water for the offshore petroleum industry in Campos Basin (SEA and INEA, 2014), responsible for almost $80 \%$ of Brazil's oil and gas production.

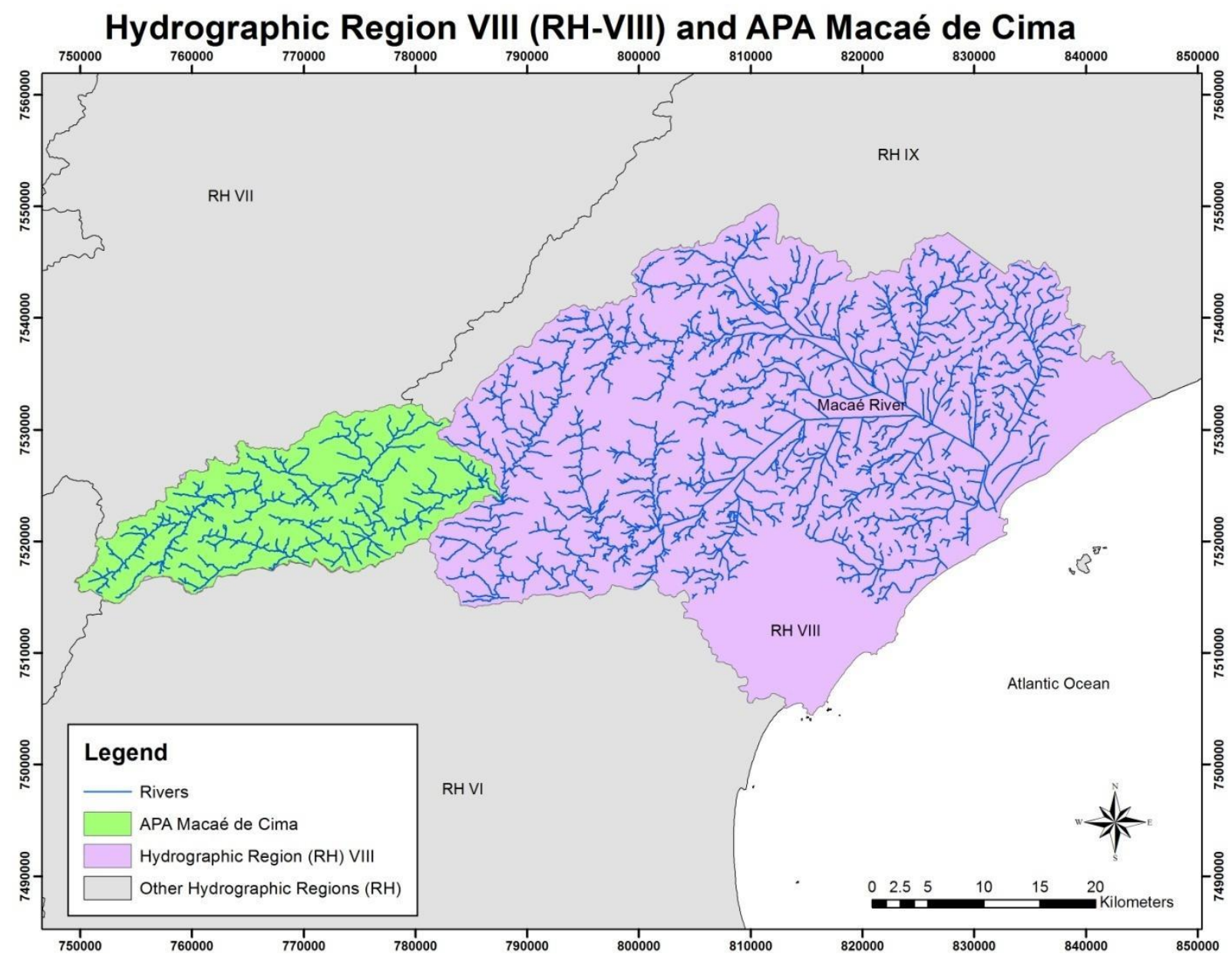

Figure 1. Macaé River Basin and EPA Macaé de Cima. Source: SEA and INEA (2014) (adapted by the authors). 
The Macaé River headwaters are located in the Environmental Protection Area of Macaé de Cima (APA Macaé de Cima), near Tinguá Peak (1560m). According to the Brazilian National System of Nature Conservation Units (SNUC), conservation areas must have Management Councils in order to enforce integrated conservation strategies involving different types of specially protected territorial spaces and their surroundings. APA's Advisory Council was created in 2005. From the perspective of environmental government agencies, the area of $350 \mathrm{~km}^{2}$ that constitutes the APA is crucial to ensure the establishment of a biodiversity corridor in Serra do Mar, providing connection between smaller fragments of Atlantic Rain Forest to other forested parcels of the Paraíba Valley. Since 1991, Atlantic Forest biome has been a Brazilian UNESCO Biosphere Reserve. All biosphere reserves must serve as demonstration sites for three functions: environmental protection, logistical provisioning for scientific research and education, and sustainable resource use (Reed, 2007). Once designated, UNESCO requires that biosphere reserves serve their region and the world as sites of excellence that demonstrate improved ways to resolve human/environment conflicts through local community efforts and sound science.

The Mount Arrowsmith Biosphere Region (MABR) is located within the Traditional Territories of the Snaw Naw As First Nation, Qualicum First Nation, Hupacasath First Nation, Snuneymuxw First Nation, and K'ómoks First Nation (AWSERWS, 2015). This Biosphere Reserve includes the ecosystems and the 45,000 people who reside within an approximately 800 square kilometre area as shown in Figure 2.

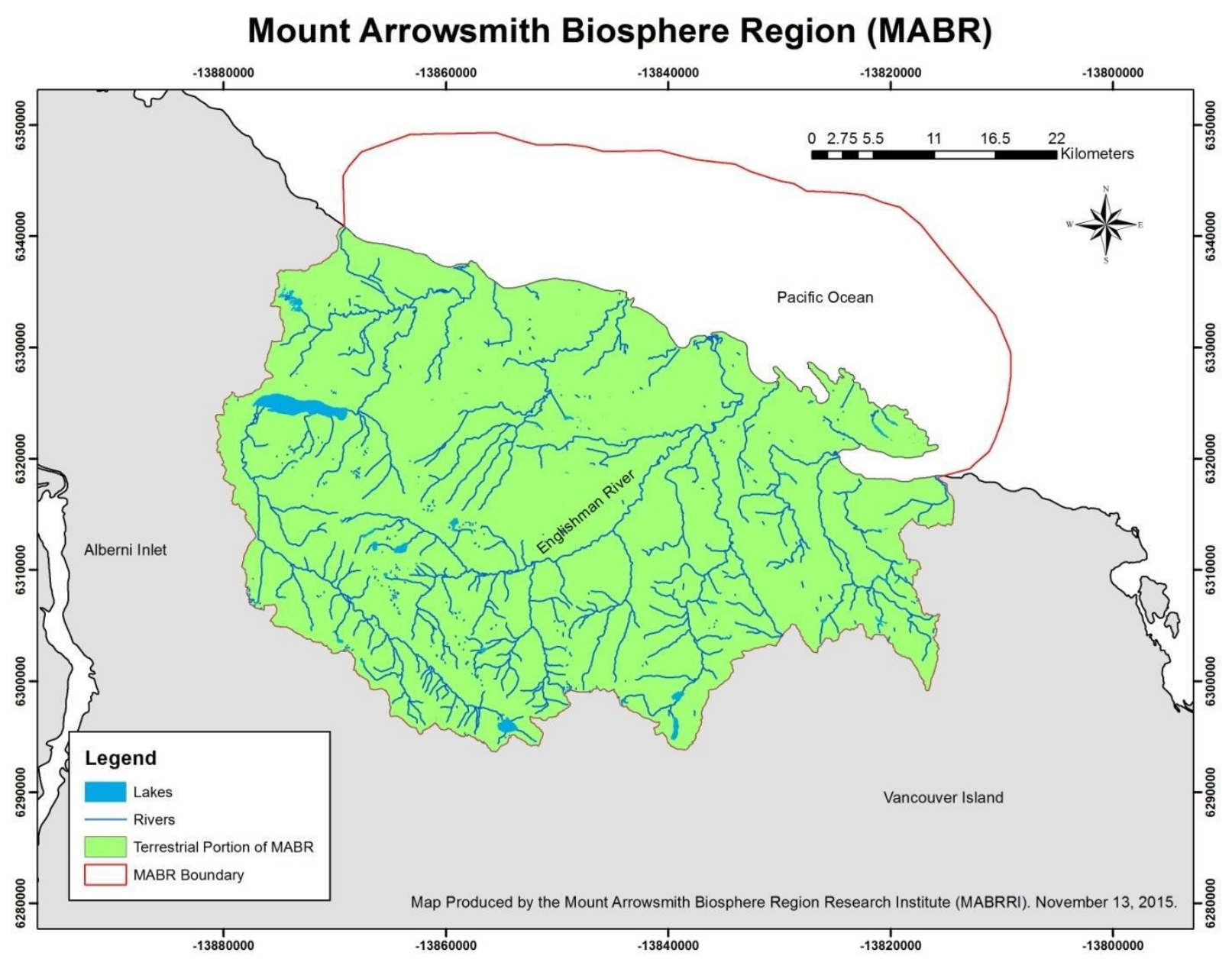

Figure 2. Mount Arrowsmith Biosphere Region 
The biogeographic zones range from high alpine (1817 meters at the peak of Mount Arrowsmith) to 300 metres below sea level, and the range of activities within the Biosphere Reserve include all those typical of Vancouver Island: forestry, aquaculture, and agriculture, as well as a spectrum of densities of rural to urban land uses (Swerhun et al., 2009). UNESCO granted this designation in 2000, and it is critical to note that this designation does not come with any form of jurisdictional authority, for this or any biosphere reserve. The designation is intended to identify areas that are environmentally significant and impacted by human activities, then each biosphere reserve organization must seek out locally applicable methods to work with levels of government and citizens through cooperative decision-making processes to improve the connection between humans and nature.

The majority of lands within the MABR are privately owned by two forestry companies, with the remainder held by private owners and levels of government. Current issues within the MABR include citizen concerns with ongoing forestry and mineral extraction activities, aquifer recharge, dams in the upper regions of the headwaters, environmental protection, urban growth, lake and wetland protection, water use, the protection of water for salmon (and other aquatic species), and the impacts of climate change on all habitats, land uses, and people (AWSERWS, 2015; Bodtker et al., 2009). The boundaries of the MABR (Figure 2) are based on watersheds and encompass the headwaters on Mount Arrowsmith, Mount Moriarty, Mount Cokely, and the Nanoose peninsula. The MABR includes the complete watersheds of the Little Qualicum River, French Creek, Englishman River, Bonnel Creek, and Nanoose Creek. The MABR also includes the Ballenas/Winchelsea Islands archipelago and the surrounding marine area, six provincial parks, and the Parksville-Qualicum Beach Wildlife Management Area.

\section{RESULTS AND DISCUSSION}

In Brazil, the balance between economic development and environmental protection was first addressed in the Brazilian Environmental Policy that was adopted into law in the early 1980s (with Federal Law 6.938, 1981). After almost a decade of applying constitutional principles, Brazilian Water Law was promulgated in 1997 (Federal Law 9.433). Brazilian Water Law states that water is a common good and essential to life; balance must be achieved among economic, ecological and social values. Water scarcity (even in tropical areas) presents the greatest challenge regarding the regulation and conciliation of these multiple uses, and in scarcity situations, by law, the priority is to ensure water is available for consumption by humans and animals.

One of the major innovations introduced by this law compared to other previous water governance models was decentralization of the decision-making process, shifting from government centered to a decentralized and participatory model. Tenure water rights are held only by the federal and state government, but some water-related policies can be held at municipal levels (Libanio, 2014). Like many other Latin American countries did when reforming their water institutions (Novo and Garrido, 2014; Jacobi et al., 2014), Brazil has adopted an integrated watershed resources management approach: Brazilian Water Law established the National Water Resources Policy (PNRH) and created the Integrated Water Resources Management System (SINGREH).

Complementary to Federal Law 9.433, Federal Law 9.985 (2000), regulated by Federal Decree 4.340 (2002) established the SNUC. This system instituted the federal policy aimed at the in situ protection, preservation and conservation of the ecosystems by means of different types of protected areas, each exercising their specific functions in the system as a whole: integral protection conservation areas in which direct use of environmental resources is not allowed; and sustainable use conservation areas with restricted and sustainable use of natural resources. Theoretically both policies have adopted the principles of democratic, decentralized 
and integrated management, present in the 1988 Federal Constitution, and drawn up in the country's democratization from strong pressure of social movements.

In Canada, the management of watersheds is under the jurisdictional responsibility of three levels of government. At the federal level, the Constitution Act (1867) sets out the responsibilities of the federal and provincial government; the text does not specifically reference watershed management, and over time legislation, regulations, and policies relating to watershed management have developed at federal, provincial, and local government levels. The federal 1999's Canadian Environmental Protection Act (CEPA) focuses on pollution prevention and the protection of humans and the environment from toxic substances. Other key acts implemented at the federal level that contribute to environmental protection, pollution prevention, and biodiversity and conservation are: the Fisheries Act (1985), Canada Wildlife Act (1985), Species at Risk Act (2002), Migratory Birds Convention Act (1994), and the Canada Water Act (1985). The latter is concerned with water quality management and was adopted to ensure that water is conserved, developed, and utilized in the most efficient manner to benefit all citizens. The remaining federal acts are primarily focused on the protection of ecosystems and avian, aquatic, and terrestrial species.

At the provincial level, British Columbia's 2016 Water Sustainability Act (WSA) sets out regulations for water use and protection in BC. Other key acts that establish the regulatory environment for water-related management include the 2015 Forest Range and Practices Act (FRPA, which regulates crown lands) and the 2003 Private Managed Forest Land Act (PMFLA, which regulates private lands) and these provide frameworks for forestry activities within watersheds. The FRPA strives to protect water sources and ensure healthy riparian areas. The PMFLA also aims to protect water quality during and following timber extraction, and also sets out regulations for protecting fish and wildlife habitat. In addition, the province has responsibilities for issuing licensing or lease arrangements to users within watersheds. Provincial authorities also have jurisdictional responsibilities in watersheds pursuant to the Environmental Management Act (2004), Environment and Land Use Act (1996), Fish Protection Act (1997), Forests Act (1996), Water Protection Act (2001), Wildlife Act (2009), and the Riparian Area Regulation (2004).

Through the Community Charter and Local Government Act, local governments are involved in watershed management through the provision of potable water to citizens, adoption of land use regulations, the establishment of development permit areas to protect environmentally sensitive areas. These responsibilities are shaped by provincial legislation, but the application and form of bylaws and services can differ substantially among local governments.

For the area under investigation, the Regional District of Nanaimo, Town of Qualicum Beach, and the City of Parksville maintain jurisdiction over local land uses and are the authorities for the provision of water to their respective citizens. The three local governments voluntarily consult with each other on issues of water provision and are also partners in the Regional Growth Strategy (along with the District of Lantzville and the City of Nanaimo, which are outside the watersheds under investigation); this document sets out eleven broad goals for the partner local governments, including goals to "enhance the environment" and "encourage cooperation among jurisdictions" (Nanaimo, 2011). Each level of local government also has implemented official community plans that set out land use designations, and each has adopted zoning bylaws that implement these official community plans on a lot by lot basis. First Nations, non-governmental organizations, and environmental groups also contribute to environmental protection initiatives. This collaboration between governments, organizations, and other stakeholders is vital to the overall success of environmental management and sustainability in Canada. 
Although legislation in Canada and Brazil developed from different colonial and legal traditions (British for the former and Portuguese for the latter) there are similarities between the legislative frameworks in the two jurisdictions, including hierarchies of jurisdiction, overlapping authorities, and the evolution of new, locally focused regulatory regimes at the local government level. Additionally, there are commonalities in that both jurisdictions have been shaped by long histories of natural resource extraction: petroleum industry and thermoelectric plants in the Brazilian case; and forestry and mining in the Canadian case. Extractive activities continue in both jurisdictions, resulting in positive economic benefits for workers and economies, but negative impacts for the environment. In both jurisdictions extractive users have improved their practices over decades of activity, in part due to regulatory changes and in part due to industry-initiated best practices and refocused mandates that consider a longer-term perspective of resource management. These commonalities ensure that comparisons between the two jurisdictions hold relevance, and opportunities to learn from each other abound.

However, there is one key difference in the approaches taken to protect and manage watersheds: in Brazil, the formation of Watershed Committee (WSC) that is given jurisdictional responsibilities has reshaped the relationship between levels of government and has allowed the achievement of concrete, locally determined actions. A similar approach has not been adopted at local, provincial, or federal levels for the area under consideration in Canada, creating a situation where working together toward shared objectives is organizationally and practically much more tenuous. The main role played by the WSCs is conflict mitigation. These "water parliaments" are advisory, deliberative, and legislative bodies for integrated and decentralized water management in the territory under their responsibility. Though cited elsewhere to be similar to Mexican advisory commissions (Grigg, 2008), Brazilian WSCs are autonomous multi-stakeholder forums empowered with budgets from charging for bulk water uses. They promote participation of representatives of water users, public authorities (from the three government levels, federal, state, and municipal), organized civil society environmental organizations, and teaching and research institutions in water governance. Funding for conservation areas (CA) comes from federal or state governments.

Going from the federal to the regional level, in Brazilian case, the state of Rio de Janeiro promulgated its State Water Law (Law 3.239/1999), establishing State Water Resources Policy and creating a State System for Water Resources Management (SEGRHI) shortly following the Federal Water Law. This new model of environmental governance was influenced by the concept of IWRM in its broader sense, as described in Brazilian Water Law (Libanio, 2014) but established macro-environmental regions as the territorial basis for environmental and water planning and management. To implement the macro-environmental regions, state government stimulated the formation of inter-municipal consortia, engaging municipalities, users of natural resources and civil society organizations as co-responsible for designing environmental planning and management. Among the diversified attributions of macro-environmental intermunicipal consortia was the promotion and implementation of WSCs. An important point in state environmental policy was the regulation of the State Fund for Water Resources that enabled each State WSC to invest in watershed conservation and management following the board's deliberations on budget applications, which reinforced participatory autonomous mechanisms.

In Canada as in Brazil, there are various mechanisms for managing environmentally sensitive areas governed by layers of jurisdictional authorities. All three levels of government (federal, provincial, and local) engage, to varying degrees, in referral processes to other levels of government. That is, legislation and regulations often contain sections that require a level of government to provide draft documents, data, or other information to other levels of government as part of a decision-making process and prior to the final consideration of a project

\section{IPABH}

Rev. Ambient. Água vol. 13 n. 3, e2225 - Taubaté 2018 
or action. The three levels of government are often required to engage with local indigenous governments, as well, through referral or formal consultation processes. The development of non-governmental organizations that are given jurisdictional authority by levels of government for managing sensitive areas is not a mechanism that is well-developed in Canada. There are examples where agencies have banded together in affiliations or committees to share information and work toward common goals (for example, various estuary committees on the east coast of Vancouver Island), but these groups do not have jurisdictional authorities over land or water management.

The State APA Macaé de Cima was created by State Decree 29.213. With a total area of 350 square kilometers, it transformed almost $40 \%$ of the municipal territory into a protected area, without any public consultation with local small farmers, and no regard to the brand new SNUC Law. Small farmers did not accept the creation of the APA, and recognized themselves as "traditional populations" struggling for the "right decision" with respect to the territory they have occupied for generations. The farmers showed concern for their survival and called themselves "the true environmentalists" and felt "punished for having preserved the forests in the region, while the rest of the world was destroying nature". Furthermore, the APA Macaé de Cima was facing federative conflicts caused by the lack of integration of different spheres of political power (municipality versus state government agencies, and state environmental agencies versus themselves). As stated by Grigg (2008), poor interactions among government units are additional institutional barriers to IWRM.

Similarly to what happened with RH VIII`s PRH and dissimilarly to other literature reported examples (Giordano and Shah, 2014), in the APA`s case its Management Plan was not undertaken to satisfy donors' (nor officers') interests. On the contrary, its elaboration was an example of the mobilization of counselors, who used their technical and local knowledge to change the technocratic tone of the originally proposed document. In the same way of the RHVIII's PRH, a great focus of controversy was the presence of family farming and their relationships with the preservation and conservation of Atlantic Rain Forest, the crucial point of conflict in the region. Mediation of this conflict was achieved by rezoning and expanding agricultural lands in APA. The Management Plan was concluded in late 2014. Re-enforcing participatory environmental conservation policy, INEA reviewed the original composition of the Advisory Council of APA Macaé de Cima, which has now has 30 members in total, and twenty civil society institutions, all local.

The above-noted structures are not without their critics. Some advocate the lack of evidence or poor reports about the benefits of IWRM (Giordano and Shah, 2014). Moreover, it is said that in spite of its solid legal framework and modern policy principles, SINGREH has failed to fill the void that still exists between national, state and local government cooperation to solve serious water management issues linked to urban and rural pollution and water scarcity in conditions of increasing water demands (Libanio, 2014). The author depicts a risk of moving backward to centralized governance models, although he does recognize that over the past twenty years there have been significant gains in citizen participation. We consider that "granted participation" (the attempt to control the actions of various groups, associations and individuals within the desired limits of government agencies) represents the major risk to IWRM. These limits can be surpassed and then participation can become a real instrument for strengthening citizenship. In this way, civil society has a fundamental importance for enhancing collaborative governance mechanisms as we can see deconstructing the case of RH-VIII in Rio de Janeiro.

With respect to the Canadian case study, when the MABR was founded in 2000 the original management structure conformed to the requirements of the BC Society Act as the biosphere was incorporated as the non-profit Mount Arrowsmith Biosphere Foundation). This included 
requirements for an elected board, annual general meetings, filings with the provincial government on budgets and activities, and the right of membership for residents interested in being a part of the MABR. In the decade up to 2010, this management method proved problematic as difficulties ensued in identifying the purpose, mission, and practical actions that could be taken to address the relationship between humans and nature in the MABR. In addition, there was a history of distrust among levels of government, First Nations, private landowners, environmental groups, and business interests in the MABR, which made the definition and the movement toward shared goals challenging. This became apparent with the conclusions reached by the UNESCO-appointed review committee for the Ten Year Periodic Review for the MABR (Reed et al. 2010). As noted in the report, ongoing disagreement on the purpose and objectives of the biosphere region caused turnover in the board of directors, and limited goal definition and achievement. The report noted that these differences appeared to be consuming much of the attention of the organization, instead of creating opportunities for working toward goals shared among First Nations, forestry companies, government, environmentalists and other regional stakeholders, as should be the focus of a biosphere reserve. At issue as well was a lack of ongoing funding to sponsor activities, conduct research, or complete outreach activities in the communities.

The Periodic Review Report energized activities focused on protecting the UNESCO designation and moving to practical actions to improve the human/environment relationship in the MABR. The directors of the Mount Arrowsmith Biosphere Foundation dissolved the nonprofit society status of the organization in 2014, and a new partnership and governance structure was formed between Vancouver Island University (VIU) and the City of Parksville. For VIU, the MABR provided a focus for a variety of student-based research initiatives through the newly created Mount Arrowsmith Biosphere Region Research Institute. For the City of Parksville, the Biosphere Reserve added to the unique identity of the region and emphasized that the midIsland is a place of innovation and learning. Since the founding of this partnership, the Town of Qualicum Beach has signed a Memorandum of Understanding and joined the management structure, and two local First Nations (Qualicum First Nation and Snaw Naw As First Nation) have expressed support for the new management structure and the MABR. The management approach now takes the form of a roundtable with recognition given to the First Nations as having historic jurisdictional authority over all lands and waters within their Traditional Territories, and new participants from government agencies and citizen representatives have joined the roundtable. Operationally, all partners sit at the roundtable as representatives of their agency or level of government. The roundtable partners are working to establish protocols that will recognize the complexities relating to overlapping jurisdictions. All agree that they are in attendance to share information, report on planned activities, and discuss actions that can work toward common objectives. The intent is to provide a democratic, non-hierarchical method for working toward shared goals on human/nature interactions.

\section{CONCLUSIONS}

There are lessons to be learned by the MABR from the evolution of WSC and APAs Council in Brazil. Perhaps most important is the recognition of local citizens and stakeholders in a decision-making process that provides for the "delegated power" and "citizen control". Equally important is the recognition provided to the WSC by levels of government. The designation of a biosphere reserve does not come with a new and superseding level of regulatory authority over the lands, waters, users, agencies, or citizens within their identified area. Instead, the managers and participants in a biosphere reserve must work within federal, provincial, and local government mandates to foster an improved connection between humans and nature. A second lesson focuses on communications: there must be an open, transparent process for 
sharing information, and participants must feel respected and heard. The proponents in Brazil recommend multiple means of communication, not limited to the use of digital tools that may turn out to be exclusive or difficult for some community members. An additional issue for the participants in the MABR be the assurance of confidentiality: each of the participants must be able to commit to a process where dialogues that take place at a meeting are held as confidential among all participants until the group agrees that information can be made public. A final lesson is the need to focus on a common goal: for the WSC, this was guaranteeing a water supply through the development of a Hydric Resources Plan and the implementation of APA's Management Plan. For MABR, this shared goal is still to be realized. It is anticipated that an approach that involves all parties in the determination of goals and objectives will be the best method for moving from ideas to positive actions. This appears to be true across biosphere reserves in Canada: similar findings regarding water quality, conservation and management of land, and ecosystem services were reported by UNESCO in their review of the Canadian reserves (UNESCO, 2013).

The process to create a WSC in Brazil ultimately appears to be a workable, practical, and achievable method for moving jurisdictional responsibility and decision-making to a more local level in a manner that involves a wide range of stakeholders in a cooperative and productive forum for positive change. The current governance model in the MABR - an alliance of roundtable partners, is not yet proven, but there is optimism among participants that a more successful and productive relationship can be achieved that recognizes the unique characteristics of the region, the longstanding sovereignty of First Nations over the lands, and UNESCOs objectives for advancing science, education, and cultural activities.

\section{ACKNOWLEDGMENTS}

The authors wish to thank the Brazilian Governmental Research Agency - CAPES for funding this study (grant no. BEX 2577/15-1). They also wish to thank the Federal Fluminense Institute and Vancouver Island University for staff support as well as the interviewees from the two studied areas for sharing their knowledge and experience.

\section{REFERENCES}

\section{ARROWSMITH WATER SERVICE; ENGLISHMAN RIVER WATER SERVICE - AWSERWS. Fisheries Benefits. Available: http://www.englishmanriverwaterservice.ca/fisheries_benefits.asp. Access: 4 Nov. 2015.}

BODTKER, K. M.; PELLATT, M.G.; CANNON, A. J. A bioclimatic model to assess the impact of climate change on ecosystems at risk and inform land management decisions. Report for the Climate Change Impacts and Adaptation Directorate. Vancouver: Parks Canada Agency, Western \& Northern Service Centre Publication, 2009.

GIORDANO, M.; SHAH, T. From IWRM to integrated waters resources management. International Journal of Water Resources Development, v. 30, n. 2, p. 364-376, 2014. https://doi.org/10.1080/07900627.2013.851521

GRIGG, N. S. Integrated water resources management: balancing views and improving

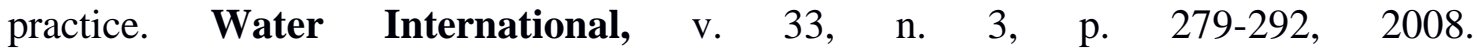
https://doi.org/10.1080/02508060802272820 
JACOBI, P. R. et al. Reforming water governance structures. In: WILLAARTS, B. A.; GARRIDO, A.; LLAMAS, M. R. (Eds.). Water for Food and Wellbeing in Latin America and the Caribbean. Social and Environmental Implications for a Globalized Economy. Madrid: Fundación Botín, 2014,

LIBANIO, P. A. C. The use of goal-oriented strategies in the building of water governance in Brazil. Water International, v. 39, n. 4, p. 404-416, 2014. https://doi.org/10.1080/02508060.2014.910433

NANAIMO. Regional District. Regional Growth Strategy Bylaw No. 1615. 2011. Available: www.rdn.bc.ca. Access: 2015.

NOVO, P.; GARRIDO, A. From policy design to implementation: an institutional analysis of the new Nicaraguan Water Law. Water Policy, v. 16, p. 1009-1030, 2014. http://dx.doi.org/10.2166/wp.2014.188

REED, M. Uneven Environmental Management: A Canadian Perspective. Environmental Management, v. 39, p. 30-49, 2007. https://doi.org/10.1007/s00267-005-0159-5

REED. M.; MENDIS-MILLARD, S.; FRANCIS, G. Mount Arrowsmith Biosphere Reserve Periodic review. 2010. Available: http://www.mabr.ca. Access: 2015.

RIO DE JANEIRO (Estado). Secretaria de Meio ambiente - SEA; INSTITUTO ESTADUAL DO AMBIENTE - INEA. Revista do plano de recursos hídricos da região hídrográfica VIII: Relatório Síntese. Rio de Janeiro: INEA, 2014. 181 p.

SWERHUN, K.; JAMIESON; G.; SMITH, D. J. Establishing GLORIA long-term alpine monitoring in southwestern British Columbia, Canada. Northwest Science, v. 83, n. 2, p. 101-116, 2009. https://doi.org/10.3955/046.083.0202

UNITED NATIONS EDUCATIONAL, SCIENTIFIC AND CULTURAL ORGANIZATION - UNESCO. Learning from each other: proven good practices in Canadian Biosphere Reserves. Ottawa: Canadian Commission for UNESCO, 2013. Available: https://goo.gl/S96peo 